\title{
Flexural Properties of Long Bamboo Fiber/ PLA Composites
}

\author{
Shinji Ochi \\ Department of Mechanical Engineering, National Institute of Technology, Niihama College, Ehime, Japan \\ Email: $\underline{\text { s ochi@mec.niihama-nct.ac.jp }}$
}

Received 19 May 2015; accepted 30 June 2015; published 3 July 2015

Copyright (C) 2015 by author and Scientific Research Publishing Inc.

This work is licensed under the Creative Commons Attribution International License (CC BY). http://creativecommons.org/licenses/by/4.0/

(c) (i) Open Access

\begin{abstract}
This paper describes the flexural properties of biodegradable composites made using natural fiber and biodegradable plastics. Biodegradable composites were fabricated from bamboo fiber bundles and PLA (polylactic acid) resin. In this research, effect of molding temperature and fiber content on flexural properties of bamboo fiber reinforced composites was investigated. The flexural strength of this composite increased with increasing fiber content up to $70 \%$. The flexural strength of composites decreased at molding temperature of $180^{\circ} \mathrm{C}$. Biodegradable composites possessed extremely high flexural strength of $273 \mathrm{MPa}$, in the case of molding temperature of $160^{\circ} \mathrm{C}$ and fiber content of $70 \%$.
\end{abstract}

\section{Keywords}

Bamboo Fiber, PLA, Biodegradable Composites, Natural Fiber, Flexural Strength

\section{Introduction}

Recently, consciousness to recycling and zero emission is increasing. FRP (fiber reinforced plastics), including glass and carbon fiber reinforced plastics, have good characterizes, such as high strength, low density and corrosion resistance. Therefore, these FRPs are extensively used in a wide range of fields, including a exterior of a motorboat, automobile parts and sport goods, etc. However, these FRPs impact the environment. They are made from fossil fuels and they are non-biodegradable. From these perspectives, the usage and disposal of conventional FRP clearly contribute to the global concerns of recycling and zero-emissions and emphasis need to be placed on the involving FRP once they have been disposed.

In the past, bamboo was used as part of daily life (e.g., bamboo shoots for food and stalks for building materials). However, recently, bamboo forests have fallen into ruin because of the appearance of plastic products and the import of inexpensive bamboo shoots. The present study investigated whether bamboo can be effectively used to replace plastic and FRP materials. 
The use of natural fibers in FRP to replace glass and carbon fibers is receiving attention, because of advantages such as biodegradability, renewability, low cost and more over. Recent researches [1]-[10] have investigated the development of biodegradable composites using natural fibers such as flax [1] [2], hemp [3] [4], banana [5], jute [6] [7], ramie [8] and kenaf [9] [10] as a reinforcement for biodegradable plastics [11] [12].

The purpose of this work is to develop the material with the biodegradability and high strength with excellent mechanical properties comparable to GFRP. In this study, long bamboo fiber bundles were selected as a reinforcement of the biodegradable composites due to their high strength. In order to increase the fraction of fibers, emulsion type PLA was used for the matrix. The unidirectional fiber reinforced composites were fabricated by hot press method. And, their mechanical properties were investigated.

\section{Experimental Procedures}

\subsection{Materials}

In this research, fiber bundles of bamboo which have diameter of 100 - $300 \mu \mathrm{m}$ and length of 100 mm were used. Figure 1 shows macroscopic photograph of bamboo fiber bundles used in this work. Steam explosion method was used to take out bamboo fibers. Steam explosion is the method when the water contains in bamboo is heated under high temperature and pressure, then bamboo is rapidly released to the atmosphere, so that the water evaporate into steam, result of parenchyma inside the bamboo shattered.

In order to produce biodegradable composites that have high fiber content, an emulsion-type PLA (Miyoshi Oil \& Fat Co., LTD.; PL-1000) was used (Figure 2). This resin contains fine particles of approximately $4.0 \mu \mathrm{m}$ in diameter suspended in aqueous solution with a mass content of approximately $40 \%$. The molecular weight of used PLA is around180,000.

\subsection{Molding Method of Biodegradable Composites}

First, preliminary composites were produced by putting the biodegradable resin on the surface of bamboo fibers

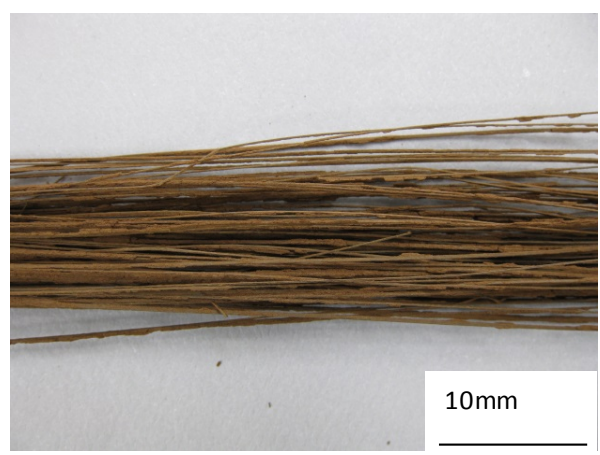

Figure 1. Photograph of bamboo fiber used in this work.

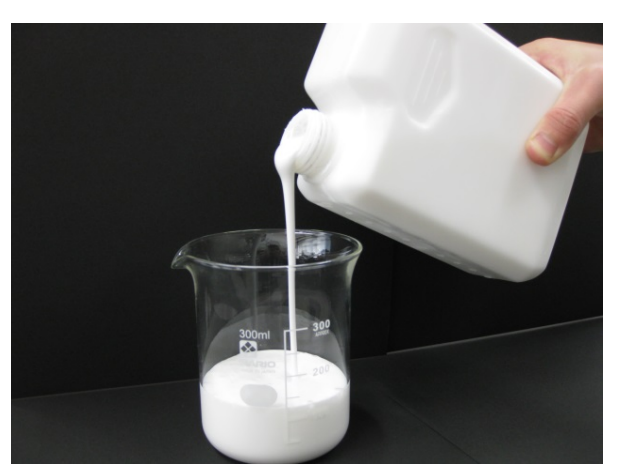

Figure 2. PLA of emulsion type. 
and drying at $105^{\circ} \mathrm{C}$ for $120 \mathrm{~min}$ in an oven. Next, biodegradable composite specimens were fabricated by hot pressing using a pressing machine. In this process, the preliminary composites were set in a metallic mold and heated to $120^{\circ} \mathrm{C}, 140^{\circ} \mathrm{C}, 160^{\circ} \mathrm{C}, 180^{\circ} \mathrm{C}$ and $200^{\circ} \mathrm{C}$ with hot-press machine. The metallic mold was held at $120^{\circ} \mathrm{C}$ $-200^{\circ} \mathrm{C}$ for $5 \mathrm{~min}$ and specimens were hot-pressed at $10 \mathrm{MPa}$. The dimensions of the biodegradable composite specimens were $15 \mathrm{~mm} \times 100 \mathrm{~mm} \times 3 \mathrm{~mm}$ for flexural testing (Figure 3). The volume fraction of bamboo fiber in the specimens was varied from $0 \%$ to $70 \%$. Table 1 was showed molding condition in this research.

\subsection{Method of Flexural Test}

Three-point flexural tests were conducted using a testing machine (SIMADZU Model AG-250kNE), following JIS K7171 (plastics determination of flexural properties). Flexural tests were performed at a crosshead speed of $1 \mathrm{~mm} / \mathrm{min}$ and a span length of $48 \mathrm{~mm}$ as shown in Figure 4. Five specimens were prepared and analyzed. A 95\% confidence interval was calculated by statistical analysis.

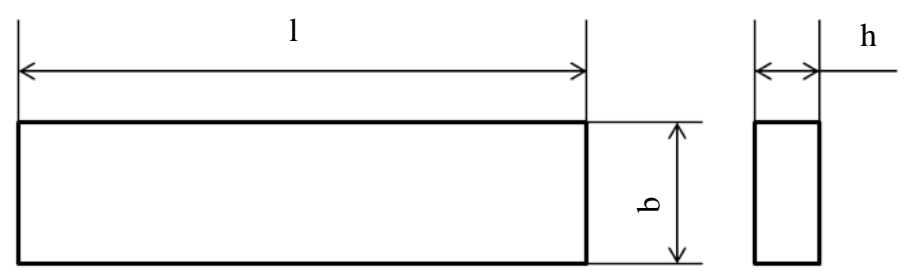

Figure 3. Shape and dimensions of flexural specimen $(\mathrm{l}=100 \mathrm{~mm}, \mathrm{~b}=$ $15 \mathrm{~mm}, \mathrm{~h}=3 \mathrm{~mm})$.

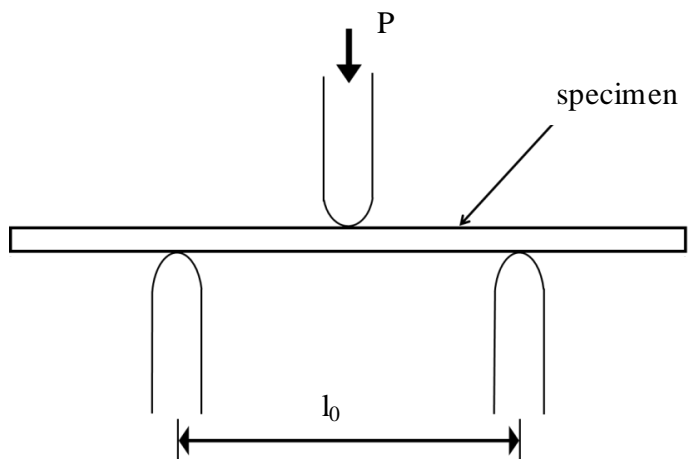

Figure 4. Method of three-point flexural test $\left(\mathrm{l}_{0}=48 \mathrm{~mm}\right)$.

Table 1. Molding condition (temperature, fiber content).

\begin{tabular}{ccc}
\hline Molding temperature $\left({ }^{\circ} \mathrm{C}\right)$ & Bamboo fiber (\%) & PLA (\%) \\
\hline 120 & 50 & 50 \\
140 & 0 & 100 \\
160 & 30 & 70 \\
& 50 & 50 \\
180 & 70 & 30 \\
200 & 50 & 50 \\
\hline
\end{tabular}




\section{Results and Discussions}

\subsection{Fabrication of Composite Materials}

The top view of the biodegradable composites with 0 and $70 \%$ of fibers molded at $160^{\circ} \mathrm{C}$ are shown in Figure 5 . From this figure, a color of PLA specimen is milky. The other, it of bamboo fiber of $70 \%$ is dark brown. It can be observed that the distribution of fibers is parallel, and that there are no voids that would cause a decrease in strength. The novel technique presented herein, which uses an emulsion-type biodegradable resin, provides a suitable internal environment for achieving high fiber volume, in which voids are reduced in the composites.

Figure 6 shows top views of biodegradable composites of 50\% fiber content. Figures 6(a)-(d) indicate specimens molded at $120^{\circ} \mathrm{C}, 160^{\circ} \mathrm{C}, 180^{\circ} \mathrm{C}$ and $200^{\circ} \mathrm{C}$, respectively. From Figure $6(a)$, resin doesn't finish melting in case of $120^{\circ} \mathrm{C}$, and it's the turbid color. From Figure 6(b), in the case of fiber content of $50 \%$ and molded at $160^{\circ} \mathrm{C}$, there are no voids because resin melted completely. From Figure $6(\mathrm{c})$, in the case of $180^{\circ} \mathrm{C}$, voids have occurred to the surface. In the case of molding temperature of $200^{\circ} \mathrm{C}$, unevenness in the surface appears more conspicuously.

The relationship between the density of the composites of $50 \%$ fibers and molding temperature is shown in Figure 7. From this figure, the density of composites increased with rising molding temperature until $160^{\circ} \mathrm{C}$.

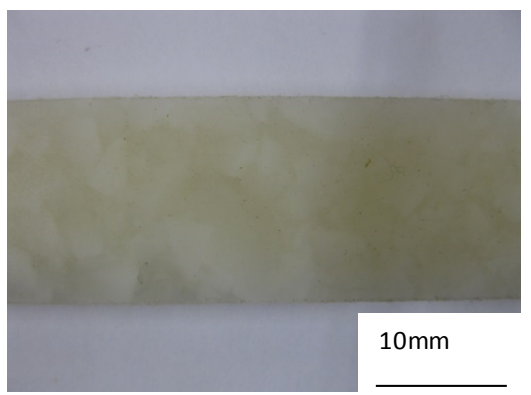

(a)

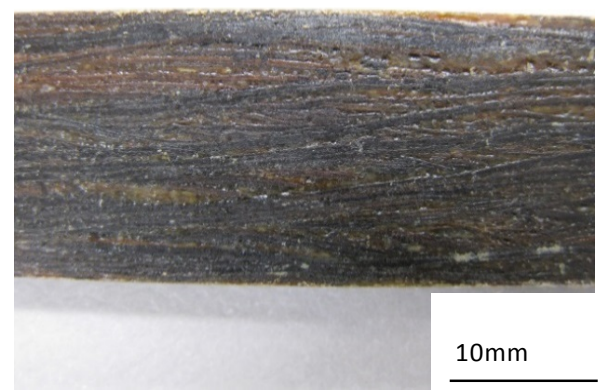

(b)

Figure 5. Photographs of top view of composites. Fiber content of (a) $0 \%$ and (b) $70 \%$.

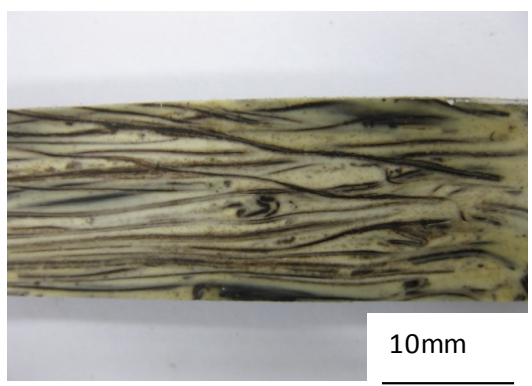

(a)

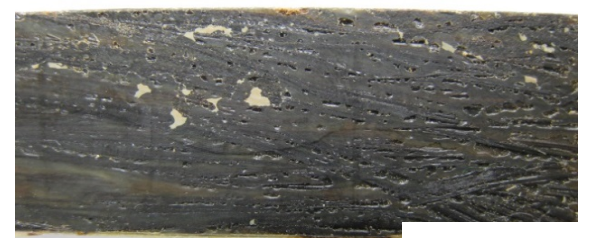

$10 \mathrm{~mm}$

(c)

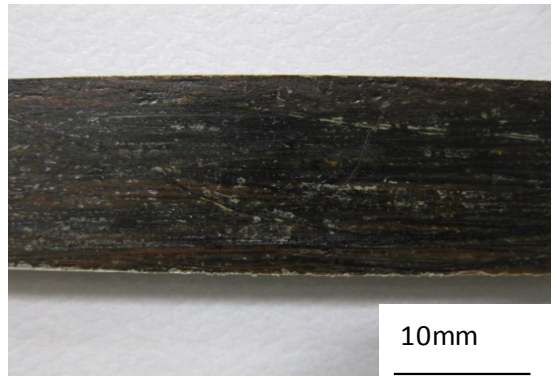

(b)

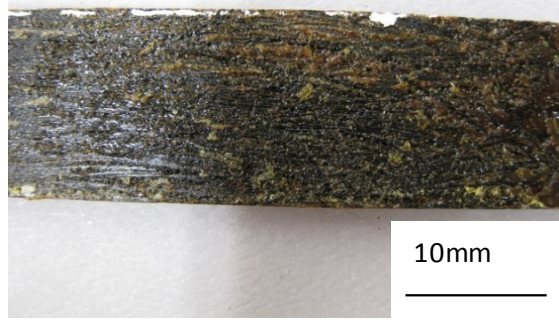

(d)

Figure 6. Photographs of top view of composites. Molding temperatures of (a) $120^{\circ} \mathrm{C}$, (b) $160^{\circ} \mathrm{C}$, (c) $180^{\circ} \mathrm{C}$ and (d) $200^{\circ} \mathrm{C}$. 


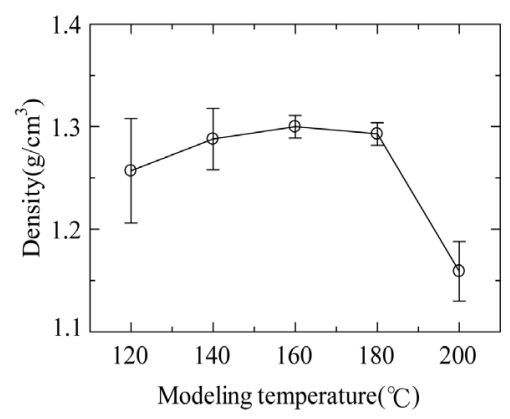

Figure 7. Relationship between density and molding temperature.

However, density decreased dramatically at $200^{\circ} \mathrm{C}$. This was expected as it was known bring many voids at temperatures above $200^{\circ} \mathrm{C}$, from Figure 6(d).

The relationship between the density of the specimens molded at $160^{\circ} \mathrm{C}$ and fiber content is shown in Figure 8. From this figure, density of specimen is increased with increasing fiber content until $50 \%$ of fibers. But, density decreased slightly at $70 \%$ of fibers. From this figure, resin isn't filled sufficiently inside the specimen. Therefore density decreased slightly at $70 \%$ of fibers.

The density of products molded at $0 \%$ and $50 \%$ of fibers are 1.24 and $1.31 \mathrm{~g} / \mathrm{cm}^{3}$, respectively.

\subsection{Flexural Strength Bamboo Fiber/PLA Composite}

Figure 9 shows the relationship between flexural strength and molding temperature. The flexural strength leveled off at molding temperature of $120^{\circ} \mathrm{C}-160^{\circ} \mathrm{C}$, but decrease after $180^{\circ} \mathrm{C}$. The strength of the mold product decreased because strength of fiber in itself decreased [13]-[15]. Therefore, it can be said that $160^{\circ} \mathrm{C}$ is the most suitable molding temperature.

Figure 10 shows the relationships between flexural strength and fiber content molded at $160^{\circ} \mathrm{C}$. From this figure, it can be seen that flexural strengths increase linearly with increasing fiber content. The flexural strengths were $273 \mathrm{MPa}$, in the samples with a fiber content of $70 \%$. This value is higher than the flexural strength of the bamboo reinforced material reported in the past [16] [17].

Figures 11-13 show fracture behavior after flexural testing. Figure 11 shows specimen molded at $120^{\circ} \mathrm{C}$. The color of specimen is milky. In the case of the specimen molded at $120^{\circ} \mathrm{C}$ there is no fracture of fibers, delamination can be seen between the fiber bundle and biodegradable resin, and bonding between the fiber bundle and the biodegradable resin is poor. In the case of molded at $160^{\circ} \mathrm{C}$ (Figure 12), it's possible to observe fracture of fiber.

In the case of specimens molded at $200^{\circ} \mathrm{C}$ (Figure 13), they explained that this cause was due to a lot of voids and low shearing stress between fiber and resin. Moreover, the strength of the mold product decreased because strength of fiber in itself decreased, from Figure 9. The composites molded at $200^{\circ} \mathrm{C}$ brought many voids (Figure 6(c)). These voids caused the decrease of density and strength.

\subsection{Flexural Modulus of FRP}

Figure 14 shows the relationship between flexural modulus and molding temperature. In the case of $120^{\circ} \mathrm{C}$, flexural modulus indicated 3.2 GPa. Flexural modules increased at $140^{\circ} \mathrm{C}$, and remain constant thereafter. As the reason that the value of $120^{\circ} \mathrm{C}$ indicated low value, from Figure 11, because adhesion force of fiber and resin is weak, it can think detaching has formed.

Figure 15 shows the relationship between flexural modulus and fiber content. From this figure, flexural modulus increases linearly with increasing fiber content. Unidirectional bamboo fiber/bamboo powder composites fabricated with fiber content of $70 \%$ and molding temperature at $160^{\circ} \mathrm{C}$ have flexural modulus of $6.8 \mathrm{GPa}$.

\subsection{Comparison with General Plastics}

Table 2 shows mechanical properties of general plastic and FRP materials. The density of bamboo fiber reinforced PLA composites indicated $1.2-1.3 \mathrm{~g} / \mathrm{cm}^{3}$. The density of bamboo composite indicated same as value of PC (polycarbonate) and POM (polyacetal). 


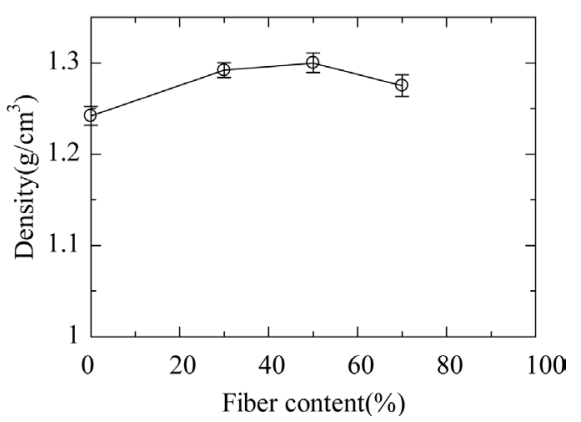

Figure 8. Relationship between density and fiber content.

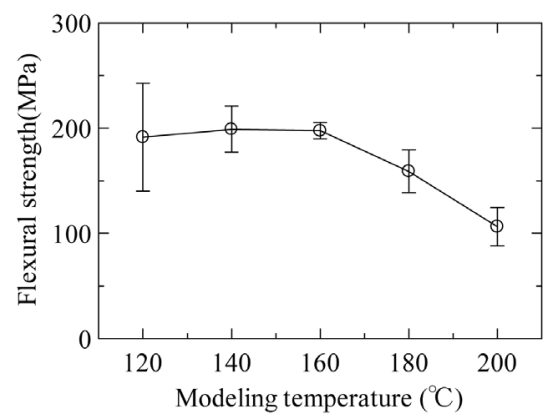

Figure 9. Relationship between flexural strength of biodegradable composites and molding temperature.

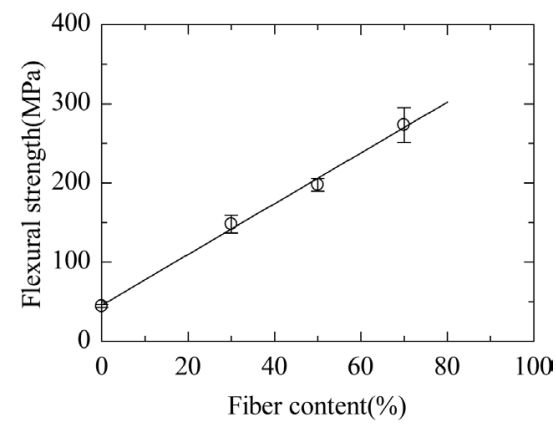

Figure 10. Relationship between flexural strength of biodegradable composites and fiber content. molding temperature of $160^{\circ} \mathrm{C}$.
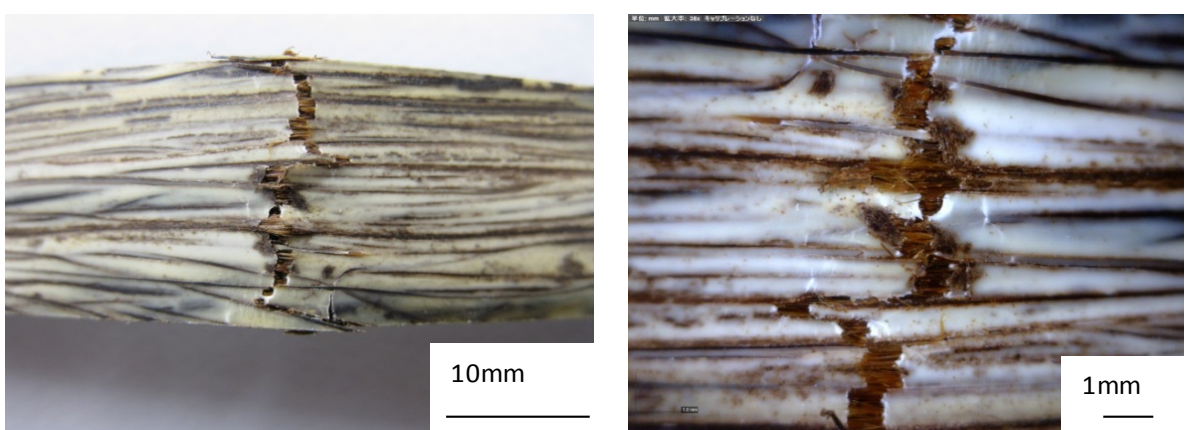

Figure 11. Fracture behavior of specimen after flexural test. Molding temperature of $120^{\circ} \mathrm{C}$. fiber content of $50 \%$. 

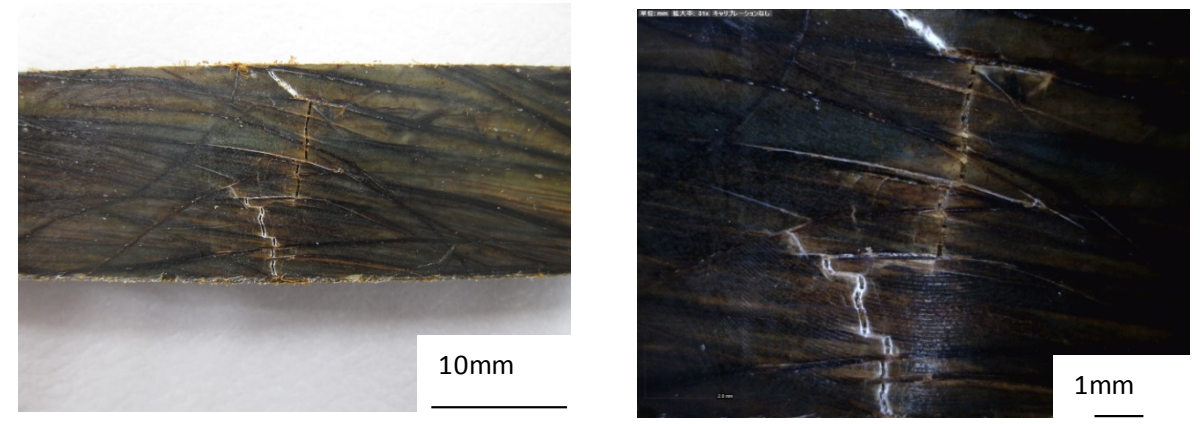

Figure 12. Fracture behavior of specimen after flexural test. Molding temperature of $160^{\circ} \mathrm{C}$. fiber content of $50 \%$.

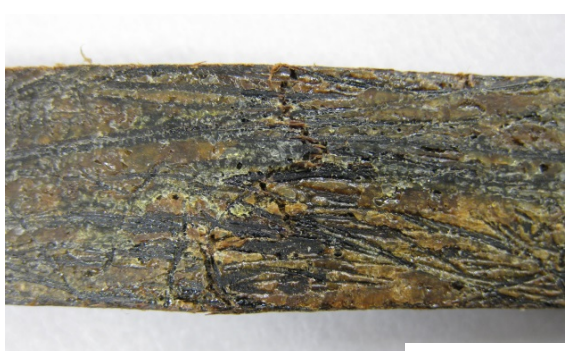

$10 \mathrm{~mm}$

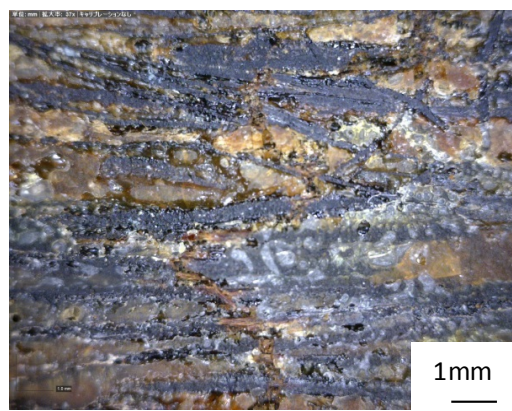

Figure 13. Fracture behavior of specimen after flexural test. Molding temperature of $200^{\circ} \mathrm{C}$. fiber content of $50 \%$.

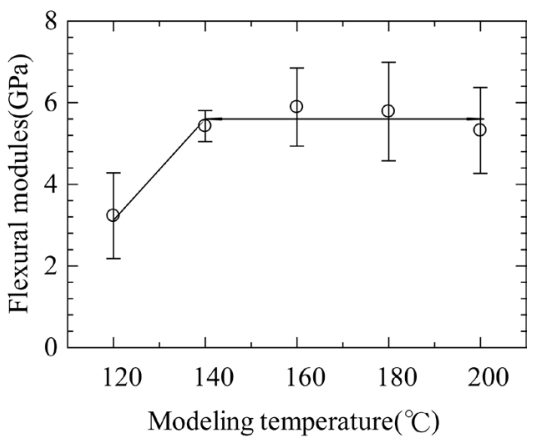

Figure 14. Relationship between flexural modulus and molding temperature. Fiber content of $50 \%$.

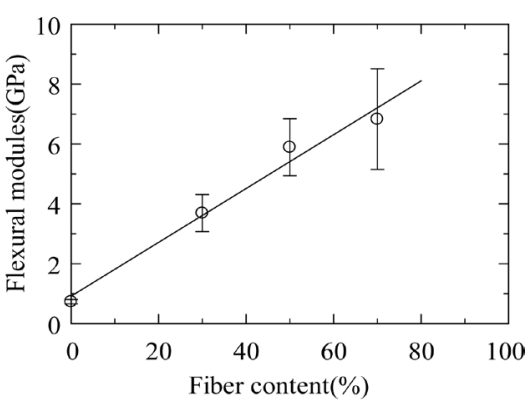

Figure 15. Relationship between flexural modulus and fiber content. Molding temperature of $160^{\circ} \mathrm{C}$. 
Table 2. Characteristics of general plastics and FRP [18] [19].

\begin{tabular}{|c|c|c|c|}
\hline & Density $\left(\mathrm{g} / \mathrm{cm}^{3}\right)$ & Flexural strength (MPa) & Flexural modulus (GPa) \\
\hline Bamboo fiber $50 \% 120^{\circ} \mathrm{C}$ & 1.26 & 191.52 & 3.23 \\
\hline Bamboo fiber $50 \% 140^{\circ} \mathrm{C}$ & 1.29 & 199.00 & 5.43 \\
\hline Bamboo fiber $50 \% 160^{\circ} \mathrm{C}$ & 1.30 & 197.60 & 5.89 \\
\hline Bamboo fiber $50 \% 180^{\circ} \mathrm{C}$ & 1.29 & 158.97 & 5.78 \\
\hline Bamboo fiber $50 \% 200^{\circ} \mathrm{C}$ & 1.16 & 106.38 & 5.32 \\
\hline Bamboo fiber $0 \% 160^{\circ} \mathrm{C}$ & 1.24 & 44.50 & 0.73 \\
\hline Bamboo fiber $30 \% 160^{\circ} \mathrm{C}$ & 1.29 & 148.08 & 3.69 \\
\hline Bamboo fiber $70 \% 160^{\circ} \mathrm{C}$ & 1.28 & 273.28 & 6.83 \\
\hline PE & 0.94 & $34-39$ & $1.00-1.55$ \\
\hline PP & 0.90 & $41-55$ & $1.17-1.73$ \\
\hline PS & 1.05 & $23-69$ & $1.10-2.69$ \\
\hline PC & 1.20 & $83-97$ & $2.28-2.35$ \\
\hline POM & 1.41 & $94-110$ & $2.62-3.38$ \\
\hline GFRP (cross ply 54\%) & 1.65 & 274 & \\
\hline GFRP (random 25\%) & 1.48 & 140 & 7.45 \\
\hline GFRP (random 50\%) & 1.63 & 222 & 13.52 \\
\hline
\end{tabular}

The flexural strength of common plastic materials, PP (polypropylene) is 41 - $45 \mathrm{MPa}$. Measurements of the press molded product of PLA resin of $100 \%$ indicated strengths nearly identical to that of PP. Measurements (197.6 MPa) of composite of 50\% fibers and at molding temperature of $160^{\circ} \mathrm{C}$ indicated a flexural strength nearly identical to that of GFRP (random). The flexural strengths ( $273 \mathrm{MPa}$ ) of the specimen of the fiber of $70 \%$ fabricated at $160^{\circ} \mathrm{C}$ exceeded the flexural strengths of GFRP (cross ply).

Based on these results, it is consider possible that bamboo fiber/powder composites could substitute effectively for conventional FRP products.

\section{Conclusions}

High strength biodegradable composites were made using an emulsion-type PLA resin as the matrix and bamboo fiber bundles as the reinforcement. The results obtained are as follows:

1) Density of composites indicated about $1.2-1.3 \mathrm{~g} / \mathrm{cm}^{3}$. This value is numerals value compare as PC and PP and low density than GFRP.

2) Unidirectional biodegradable composites fabricated using an emulsion-type biodegradable resin and bamboo fiber bundles with a fiber content of $70 \%$ at $160^{\circ} \mathrm{C}$ have high flexural strengths of $273 \mathrm{MPa}$ and flexural modulus of $6.8 \mathrm{GPa}$.

3) The flexural strength and modulus increased linearly with increasing fiber content up to 70\%. Thus excellent mechanical properties are achieved for composites fabricated by the novel technique proposed in this study in which the composites are fabricated with an emulsion-type biodegradable resin.

4) The flexural strengths were exceeded the general-purpose engineering plastics and FRP such as POM and GFRP.

\section{References}

[1] Bayerl, T., Geith, M., Somashekar, A.A. and Bhattacharyya, D. (2014) Influence of Fibre Architecture on the Biodegradability of FLAX/PLA Composites. International Biodeterioration \& Biodegradation, 96, 18-25. 
[2] Bax, B. and Müssig, J. (2008) Impact and Tensile Properties of PLA/Cordenka and PLA/Flax Composites. Composites Science and Technology, 68, 1601-1607. http://dx.doi.org/10.1016/j.compscitech.2008.01.004

[3] Oza, S., Ning, H.B., Ferguson, I. and Lu, N. (2014) Effect of Surface Treatment on Thermal Stability of the HempPLA Composites: Correlation of Activation Energy with Thermal Degradation. Composites Part B: Engineering, 67, 227-232.

[4] Baghaei, B., Skrifvars, M. and Berglin, L. (2013) Manufacture and Characterisation of Thermoplastic Composites Made from PLA/Hemp Co-Wrapped Hybrid Yarn Prepregs. Composites Part A: Applied Science and Manufacturing, 50, 93-101.

[5] Jandas, P.J., Mohanty, S. and Nayak, S.K. (2013) Surface Treated Banana Fiber Reinforced Poly (Lactic Acid) Nanocomposites for Disposable Applications. Journal of Cleaner Production, 52, 392-401. http://dx.doi.org/10.1016/j.jclepro.2013.03.033

[6] Rajesh, G. and Ratna Prasad, A.V. (2014) Tensile Properties of Successive Alkali Treated Short Jute Fiber Reinforced PLA Composites. Procedia Materials Science, 5, 2188-2196.

[7] Goriparthi, B.K., Suman, K.N.S. and Rao, N.M. (2012) Effect of Fiber Surface Treatments on Mechanical and Abrasive Wear Performance of Polylactide/Jute Composites. Composites Part A: Applied Science and Manufacturing, 43, 1800-1808.

[8] Yu, T. and Li, Y. (2014) Influence of Poly(butylenesadipate-co-terephthalate) on the Properties of the Biodegradable Composites Based on Ramie/Poly(lactic acid). Composites Part A: Applied Science and Manufacturing, 58, 24-29. http://dx.doi.org/10.1016/j.compositesa.2013.11.013

[9] Shukor, F., Hassan, A., Islam, Md.S., Mokhtar, M. and Hasan, M. (2014) Effect of Ammonium Polyphosphate on Flame Retardancy, Thermal Stability and Mechanical Properties of Alkali Treated Kenaf Fiber Filled PLA Biocomposites. Materials \& Design, 54, 425-429.

[10] Saba, N., Paridah, M.T. and Jawaid, M. (2015) Mechanical Properties of Kenaf Fibre Reinforced Polymer Composite: A Review. Construction and Building Materials, 76, 87-96. http://dx.doi.org/10.1016/j.conbuildmat.2014.11.043

[11] Ebnesajjad, S. (2012) Handbook of Biopolymers and Biodegradable Plastics. Fluoroconsultants Group, Chadds Ford, Pennsylvania.

[12] Zhao, H.B., Cui, Z.X., Wang, X.F., Turng, L.-S. and Peng, X.F. (2013) Processing and Characterization of Solid and Microcellular Poly(lacticacid)/Polyhydroxybutyrate-Valerate (PLA/PHBV) Blends and PLA/PHBV/Clay Nanocomposites. Composites Part B: Engineering, 51, 79-91.

[13] Testa, G., Sardella, A., Rossi, E., Bozzi, C. and Seves, A. (1994) The Kinetics of Cellulose Fiber Degradation and Correlation with Some Tensile Properties. Acta Polymer, 45, 47-49. http://dx.doi.org/10.1002/actp.1994.010450109

[14] Ochi, S. (2002) Mechanical Properties of Heat-Treated Natural Fibers. Proceedings of High Performance Structures and Composites, 4, 117-125.

[15] Gassan, J. and Bledzki, A.K. (2001) Thermal Degradation of Flax and Jute Fibers. Journal of Applied Polymer Science, 82, 1417-1422. http://dx.doi.org/10.1002/app.1979

[16] Porras, A. and Maranon, A. (2012) Development and Characterization of a Laminate Composite Material from Polylactic Acid (PLA) and Woven Bamboo Fabric. Composites Part B: Engineering, 43, 2782-2788. http://dx.doi.org/10.1016/j.compositesb.2012.04.039

[17] Verma, C.S., Sharma, N.K., Chariar, V.M., Maheshwari, S. and Hada, M.K. (2014) Comparative Study of Mechanical Properties of Bamboo Laminae and Their Laminates with Woods and Wood Based Composites. Composites Part B: Engineering, 60, 523-530. http://dx.doi.org/10.1016/j.compositesb.2013.12.061

[18] Osswald, T.A. and Menges, G. (2003) Materials Science of Polymers for Engineers. HanserGrderPubns, Germany.

[19] Hull, D. and Clyne, T.W. (1996) An Introduction to Composite Materials. 2nd Edition, Cambridge University Press, Cambridge. 